\title{
Zooplankton Diversity and Water Quality Assessment of Lentic Waters of Jammu, India
}

\author{
Sarbjeet Kour, Supreet Kour*, Nidhi Sharma and Deepanjali Slathia \\ Department of Zoology, University of Jammu, Jammu-180 006, India \\ ${ }^{\star}$ E-mail: supreetkour1994@gmail.com
}

\begin{abstract}
An attempt was made to study the abiotic parameters of three water bodies of Jammu region along with their impact on distribution and presence of zooplankton. The total of 49 organisms belonging to five groups of zooplankton viz Protozoa, Rotifera, Cladocera, Copepoda and Ostracoda were identified. Of the three stations, ostracods were recorded from station 1 only. Phylum Rotifera was observed to be dominant in all the three stations. Many pollution indicator species like Brachionus calyciflorus, Brachionus angularis, Keratella tropica, Polyarthra vulgaris, Filinia longiseta, Moina brachiata, and Chydorus sphaericus were recorded from Station 1. Both biotic and abiotic components indicate that station 1 is progressing towards eutrophication.
\end{abstract}

Keywords: Physico-chemical parameters, Zooplankton, Trophic status, Eutrophication, Pollution indicator

Water provides habitat to millions of aquatic organisms and of these, zooplankton form the most dynamic component. These are free swimming organisms in freshwaters represented mostly by five major groups viz Protozoa, Rotifera, Cladocera, Copepoda and Ostracoda. They have significant role in aquatic food web as they transfer energy from primary producers to secondary consumers and act as efficient live feed for fish larvae. The qualitative and quantitative studies of zooplankton help in assessing the pollution level and trophic status of any water body (Thakur et al 2013). Physico-chemical parameters of a water body are used as key factors to determine the trophic status of water bodies and their influence determines zooplanktonic existence as abiotic and biotic components are co-related in any aquatic system. The biotic components represented by zooplankton can be used as a bio tool for trophic status estimation as they react rapidly to changing ecological conditions and thus can be helpful in determining the utility level of water so present. The present work aimed to study the impact of abiotic factor on biotic components of three different water bodies of Jammu region with special emphasis on their trophic status estimation and water quality assessment.

\section{MATERIAL AND METHODS}

Study area: Jammu region is blessed with various lentic and lotic water sources. For the present study, three lentic water bodies were selected which are located at different regions of Jammu. Station 1 is a wetland situated at Gharana village (R.S. Pura) at a latitude of $32^{\circ} 32^{\prime} 26^{\prime \prime} \mathrm{N}$ and longitude of $74^{\circ} 41^{\prime} 24^{\prime \prime} \mathrm{E}$. This is a world famous wetland being breeding site of Siberian birds. Station 2 is a temple pond situated at Deeli village of Jammu district located at $32^{\circ} 40^{\prime} 38^{\prime \prime} \mathrm{N}$ latitude and $74^{\circ} 54^{\prime} 22^{\prime \prime} \mathrm{E}$ longitude. Being a sacred pond, it has religious importance. Station 3, also a temple pond situated at Bishnah village of Jammu district located at a latitude of $32.62^{\circ} \mathrm{N}$ and longitude of $74.87^{\circ} \mathrm{E}$ topographically being different from previous two as it is surrounded by agricultural fields.

Sample collection: The investigation was carried out during (March 2019-February 2020). Water sample was collected during morning hours for analysing various abiotic and biotic components. For collection of zooplankton, 50 litres of pond water was filtered through plankton net of mesh size $40 \mu \mathrm{m}$ and the filtrate was concentrated to $20 \mathrm{ml}$ followed by preservation in $4 \%$ formalin. Further taxonomic analysis was done in laboratory by observing the sample under compound microscope. For quantitative analysis of zooplankton, drop count method (Adoni 1985) was used. The abiotic parameters were analysed following APHA (1985) and identification of zooplankton was done following Kudo (1966), Pennak (1978), Adoni (1985), Michael \& Sharma (1988), Edmondson (1992) and Altaff (2004).

\section{RESULTS AND DISCUSSION}

Abiotic parameters: The $\mathrm{fCO}_{2}$ level at Station 1 was higher as compared to the other two stations (Table 1). The probable reason for this can be the thick mat of floating Eichhornia sp. which reduces light penetration thereby reducing 
photosynthesis inside water resulting in increased $\mathrm{fCO}_{2}$ level here. Relatively high BOD was obtained from this station. BOD is directly related to the amount of organic matter decomposed and its high value indicates presence of enormous amount of organic matter in this water body. High values of chloride at this station is also an indicator of eutrophy. The bicarbonates, calcium, magnesium and total hardness were high due to low water levels of this wetland. Station 2 had average values for all these abiotic parameters except for high values of phosphates which can be due to anthropogenic activities. In station 3 dissolved oxygen, carbonates, and $\mathrm{pH}$ were comparatively higher than the other two stations. High DO level of this station is an indicator of its relatively clearer status.

Biotic parameters: The total of 49 zooplankton species were recorded of which 4 species belonged to phylum Protozoa, 31 species to phylum Rotifera, 9 to Cladocera, 3 to Copepoda and 2 species belonged to phylum Ostracoda. Ostracods showed their presence at station 1 only. Muddy bottom of this station seems to be a supportive condition for their existence. Station wise qualitative analysis showed species diversity in the order Station 1(34)> Station 3(29)> Station 2(28) (Table 2, Fig. 1). The hierarchy of dominance of zooplankton present at the three stations is described below:

Station 1: Rotifera(53\%) > Cladocera(26\%) > Protozoa(9\%) $>$ Copepoda $(6 \%)=$ Ostracoda $(6 \%)$ (Fig. 2).

Station 2: Rotifera $(75 \%)>$ Cladocera $(11 \%)=$ Protozoa (11\%)> Copepoda(3\%) (Fig. 3).

Station 3: Rotifera $(72 \%)>$ Cladocera $(14 \%)>$ Protozoa $(7 \%)=$ Copepoda $(7 \%)($ Fig. 4$)$

The phylum Rotifera dominated all the three stations
(Fig. 1-4). Among rotifers, family Brachionidae was most abundant. Kour et al (2021), also observed the dominance of family Brachionidae among all zooplankton groups. Comparatively less number of copepods were recorded from all the study sites.

Correlation analysis: Station 1 had the highest species richness (Table 2) which may be due to the high organic load in this water body which supports a wide variety of life forms here. Correlation analysis of this water body revealed positive as well as negative correlation between biotic and abiotic parameters (Table 3). Among zooplankton, Protozoa and Rotifera showed significant positive correlation. Further both groups showed significant positive correlation with chloride and $\mathrm{fCO}_{2}$ and a significant negative correlation with calcium. Cladocerans were positively co-related with bicarbonates and nitrates and negatively co-related with temperature. Copepods showed negative correlation with sulphates. The positive correlation of ostracods with magnesium and total hardness was also observed. Apart

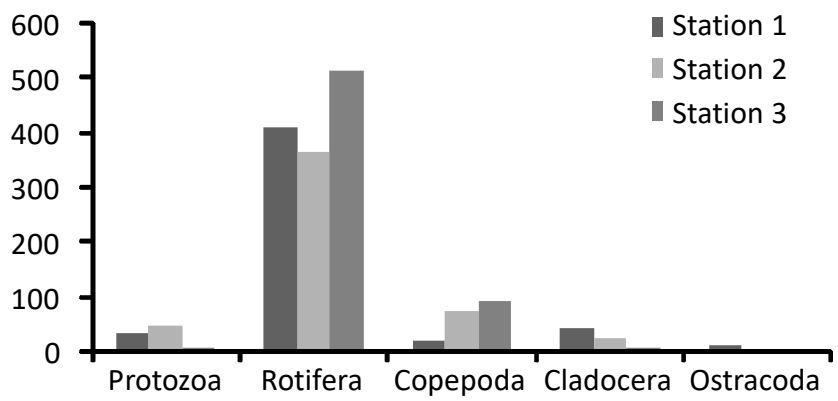

Fig. 1. Comparative abundance of zooplankton at three stations

Table 1. Annual mean values of physico-chemical parameters of the water bodies (Average $\pm S D$ )

\begin{tabular}{lccc}
\hline Abiotic parameters & Station 1 & Station 2 & Station 3 \\
\hline Air temperature $\left({ }^{\circ} \mathrm{C}\right)$ & $21.8 \pm 10.47$ & $24.5 \pm 12.58$ & $20.62 \pm 10.87$ \\
Water temperature $\left({ }^{\circ} \mathrm{C}\right)$ & $22 . .3 \pm 9.56$ & $23.2 \pm 10.43$ & $19.5 \pm 8.54$ \\
$\mathrm{pH}$ & $7.2 \pm 1.23$ & $7.4 \pm 0.298$ & $8.27 \pm 0.63$ \\
$\mathrm{DO}\left(\mathrm{mg} \mathrm{l}^{-1}\right)$ & $3.84 \pm 0.32$ & $2.02 \pm 0.48$ & $7.92 \pm 7.13$ \\
$\mathrm{fCO}_{2}\left(\mathrm{mg} \mathrm{l}^{-1}\right)$ & $27.28 \pm 26.13$ & $10.7 \pm 1.78$ & $15.84 \pm 4.89$ \\
Carbonates $\left(\mathrm{mg} \mathrm{l}^{-1}\right)$ & $7.2 \pm 3.6$ & - & $15.6 \pm 7.8$ \\
Bicarbonates $\left(\mathrm{mgl}^{-1}\right)$ & $640.09 \pm 589.07$ & $158.6 \pm 15.23$ & $306.22 \pm 244.57$ \\
Chloride $\left(\mathrm{mg} \mathrm{l}^{-1}\right)$ & $47.7 \pm 27.56$ & $23.7 \pm 6.19$ & $25.64 \pm 7.98$ \\
Calcium $\left(\mathrm{mgl}^{-1}\right)$ & $34.47 \pm 13.28$ & $33 \pm 14.66$ & $22.07 \pm 6.25$ \\
Magnesium $\left(\mathrm{mg} \mathrm{l}^{-1}\right)$ & $26.9 \pm 8.70$ & $24.5 \pm 14.84$ & $24.5 \pm 5.37$ \\
Total hardness $\left(\mathrm{mg} \mathrm{l}^{-1}\right)$ & $225.5 \pm 37.46$ & $183.5 \pm 25.21$ & $183.5 \pm 17.35$ \\
BOD $\left(\mathrm{mg} \mathrm{l}^{-1}\right)$ & $2.7 \pm 1.02$ & $2.02 \pm 0.48$ & $2.02 \pm 0.911$ \\
Phosphate $\left(\mathrm{mg} \mathrm{l}^{-1}\right)$ & $0.286 \pm 0.044$ & $0.314 \pm 0.264$ & $0.112 \pm 0.0658$ \\
Sulphate $\left(\mathrm{mg} \mathrm{l}^{-1}\right)$ & $0.002 \pm 0.0003$ & $0.0019 \pm 0.0003$ & $0.0017 \pm 0.0003$ \\
Nitrate $\left(\mathrm{mg} \mathrm{l}^{-1}\right)$ & $0.578 \pm 0.0039$ & $0.576 \pm 0.0036$ & $0.5819 \pm 0.0068$ \\
\hline
\end{tabular}


Table 2. Organisms recorded from the three stations

\begin{tabular}{|c|c|c|c|c|}
\hline Family & Zooplankton species & St. 1 & St. 2 & St. 3 \\
\hline \multicolumn{5}{|l|}{ Phylum Protozoa } \\
\hline Centropyxidae & Centropyxis aculeata (Ehrenberg) Stein & + & ++ & + \\
\hline Vorticellidae & Vorticella sp. & ++ & + & + \\
\hline Epistylidae & Epistylis sp. & +++ & + & ++ \\
\hline Difflugiidae & Difflugia accuminata (Ehrenberg 1838) & - & + & - \\
\hline \multicolumn{5}{|l|}{ Phylum Rotifera } \\
\hline \multirow{14}{*}{ Family Brachionidae } & Brachionus calyciflorus (Pallas 1766) & +++ & + & + \\
\hline & B. falcatus (Zachariad 1898) & - & ++ & +++ \\
\hline & B. caudatus (Barrois and Daday 1894) & - & ++ & + \\
\hline & B. bidentata (Anderson 1889) & - & - & + \\
\hline & B. quadridentatus(Hermann 1783) & ++ & + & + \\
\hline & B. forficula (Wierzejski 1891) & + & + & + \\
\hline & B. rubens (Ehrenberg.1838) & + & + & + \\
\hline & B. angularis (Gosse 1851) & ++ & + & - \\
\hline & B. budapestinensis (Daday 1885) & - & + & - \\
\hline & Keratella tropica (Apstein 1907) & ++ & + & + \\
\hline & Keratella quadrata (O.F.Muller 1786) & - & - & + \\
\hline & Platyias patulus(O.F.Muller 1786) & + & + & + \\
\hline & P. quadricornis (Wiszniewski 1954) & + & - & - \\
\hline & Anuraeopsis fissa (Gosse 1851) & - & + & + \\
\hline Family Euchlanidae & Euchlanis dilatata (Myers) & ++ & - & - \\
\hline Family Synchaetidae & Polyarthra vulgaris (Carlin 1943) & + & + & + \\
\hline Family Asplanchnidae & Asplanchna brightwelli (Gosse 1850) & ++ & + & + \\
\hline Family Testudinellidae & Testudinella patina (Hermann 1783) & ++ & - & - \\
\hline Family Mytillinidae & Mytilina ventralis (Ehrenberg 1832) & + & - & - \\
\hline \multirow[t]{2}{*}{ Family Epiphanidae } & Epiphanes brachionus(Ehrenberg 1837) & + & - & - \\
\hline & E. clavulata (Ehrenberg 1831) & - & + & - \\
\hline \multirow[t]{4}{*}{ Family Lecanidae } & Lecane leontina (Turner 1892) & + & + & + \\
\hline & L. curvicornis (Murray 1913) & + & ++ & + \\
\hline & Monostyla bulla (Gosse 1851) & + & - & + \\
\hline & M. decipiens (Murray 1913) & - & - & + \\
\hline Family Lepadellidae & Lepadella ovalis (O.F. Muller 1786) & + & - & - \\
\hline Family Trichocercidae & Trichocerca similis (Wierzejski 1893) & - & + & + \\
\hline Family Notommatidae & Cephalodella gibba(Ehrenberg 1832) & + & + & + \\
\hline Family Philodinidae & Philodina sp. & + & + & + \\
\hline Family Filinidae & Filinia longiseta (Ehrenberg 1834) & ++ & + & + \\
\hline Family Hexarthridae & Hexarthra mira (Hudson 1871) & - & + & - \\
\hline \multicolumn{5}{|l|}{ Phylum Arthropoda } \\
\hline \multicolumn{5}{|l|}{ Subphylum Crustacea } \\
\hline \multicolumn{5}{|l|}{ Order Cladocera } \\
\hline \multirow[t]{3}{*}{ Family Chydoridae } & Alona sp. & + & + & + \\
\hline & Chydorus sphaericus (Muller 1785) & ++ & + & + \\
\hline & Pleuroxus sp. (Baird 1843) & + & - & - \\
\hline Family Moinidae & Moina brachiata (Jurine 1820) & +++ & + & + \\
\hline Family Macrothricidae & Macrothrix rosea (Jurine 1820) & + & - & + \\
\hline \multirow[t]{3}{*}{ Family Daphniidae } & Ceriodaphnia sp. (Dana 1853) & + & - & - \\
\hline & Scapholeberis kingi (Sars 1903) & + & - & - \\
\hline & Simocepahalus vetulus (Schodler 1858) & + & - & - \\
\hline Family Sididae & Diaphanosoma sp. & + & - & - \\
\hline \multicolumn{5}{|l|}{ Subclass Copepoda } \\
\hline \multirow[t]{3}{*}{ Family Cyclopidae } & Mesocyclops leuckarti (Claus 1857) & + & + & + \\
\hline & Cryptocyclops bicolor (Sars 1863) & - & - & + \\
\hline & Eucyclops agilis (Koch 1838) & + & - & - \\
\hline \multicolumn{5}{|l|}{ Phylum Ostracoda } \\
\hline \multirow[t]{2}{*}{ Family Cyprididae } & Stenocypris sp. & ++ & - & - \\
\hline & Cypris sp. & + & - & - \\
\hline
\end{tabular}




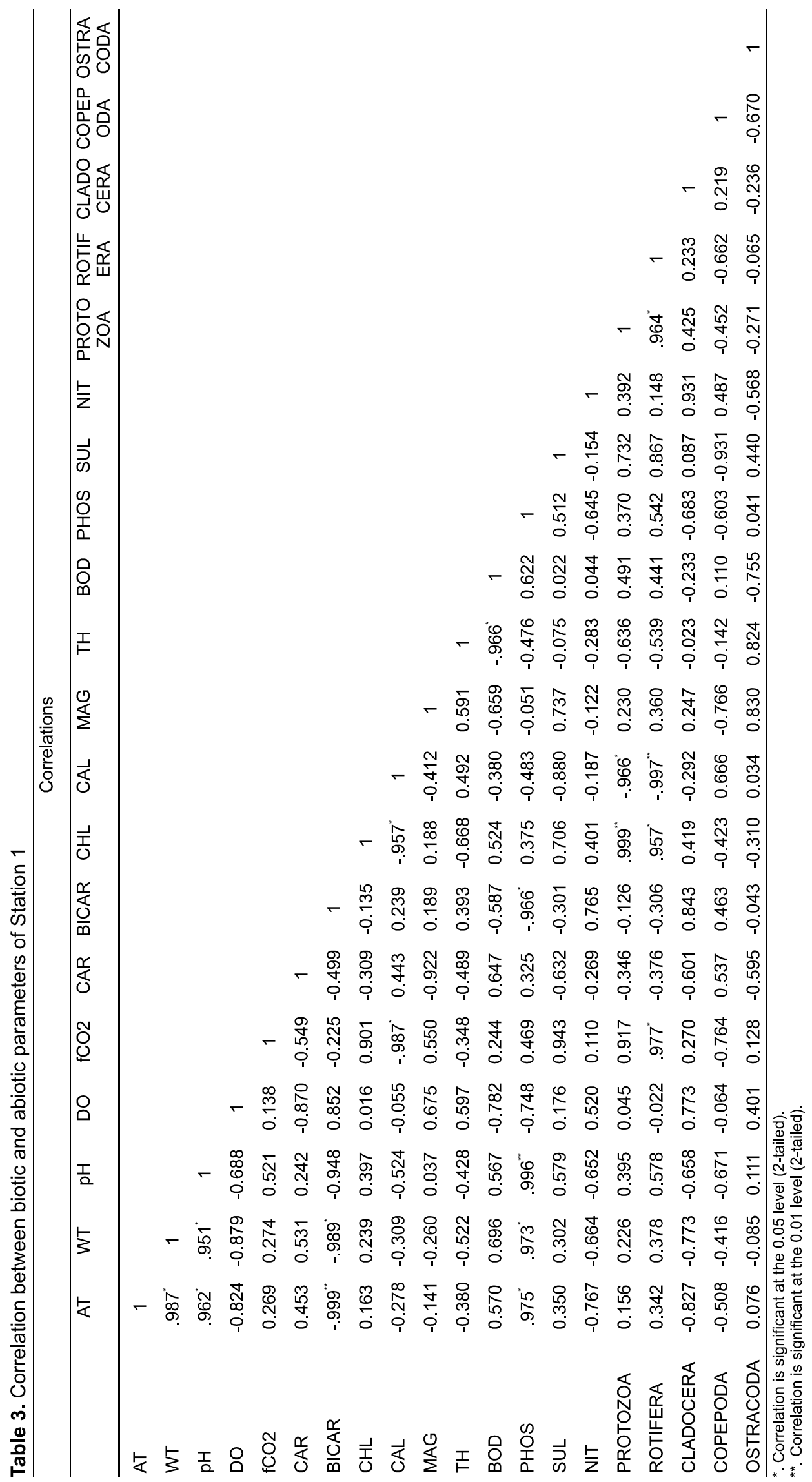


from this, bicarbonates showed a significant negative correlation with temperature and $\mathrm{pH}$. A significant positive correlation was observed between phosphates, temperature and $\mathrm{pH}$ and a significant negative correlation between phosphates and bicarbonates was observed. Chloride and $\mathrm{fCO}_{2}$ were positively correlated and both showed a significant negative correlation with calcium.

Station 2 bears the highest anthropogenic influence which is supported by less abundance of copepods in this station. In this station, a positive correlation was observed between Ostracoda and Cladocera. Ostracoda showed positive correlation with $\mathrm{DO}, \mathrm{BOD}$, magnesium and total hardness. Rotifera showed positive correlation with temperature. Cladocera, DO and BOD were positively corelated and a negative correlation was observed between Cladocera and $\mathrm{fCO}_{2}$. Chloride showed a significant positive correlation with phosphates and a significant negative correlation with sulphates. DO, BOD, magnesium and total hardness were positively co-related (Table 4)

In Station 3, cladocerans and protozoans were positively co-related. Protozoans also showed a significant positive correlation with chloride. Rotifers showed positive correlation with $\mathrm{pH}$. A significant negative correlation between cladocerans and magnesium and a positive correlation between cladocerans and chloride was observed. Copepods showed a significant negative correlation with carbonates, bicarbonates and total hardness and positive correlation with temperature and $\mathrm{fCO}_{2}$. Among abiotic parameters, a significant positive correlation was observed between carbonates,
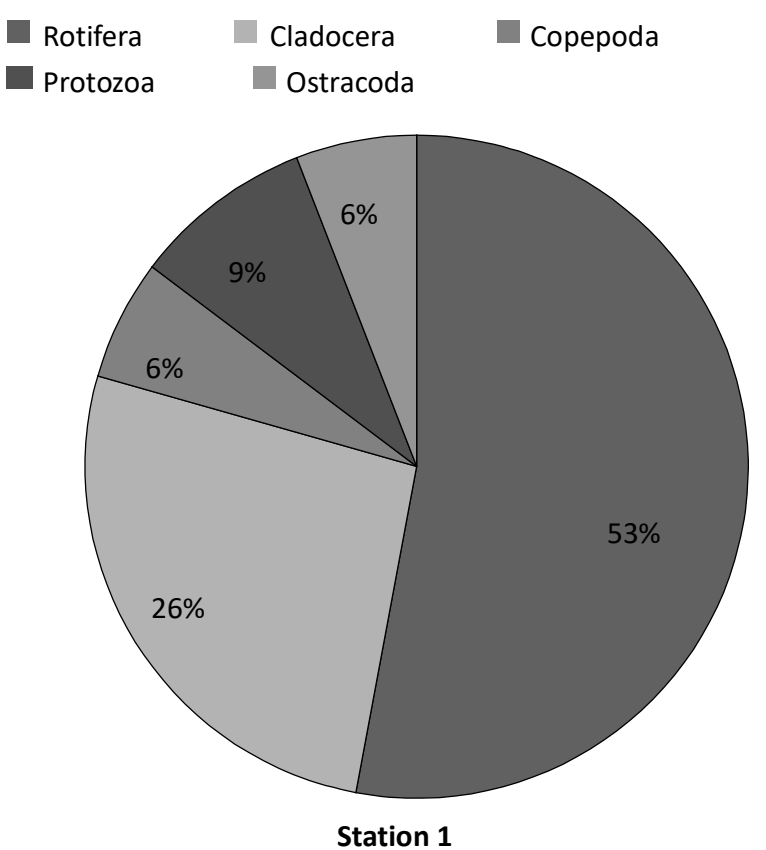

Fig. 2. Percent contribution of zooplankton at station 1 bicarbonates and total hardness. Magnesium showed negative correlation with temperature and chloride (Table 5).

Zooplankton as bioindicators: The potentiality of zooplankton as pollution indicators and their role in trophic status estimation of water bodies has long been considered by many workers (Parmar et al 2016, Ferdous and Muktadir 2009, Ramchandra et al 2006). Many pollution indicator rotifer species such as Brachionus calyciflorus, B. angularis, Keratella tropica, Filinia longiseta, Polyarthra vulgaris, Euchlanis dilatata, Testudunella patina, Asplanchna brighwelli, Cephalodella gibba were numerically abundant at station 1 (Table 2). Abundance of these pollution tolerant species in organically rich water bodies was also recorded by Thakur et al (2013) and Murkute and Chavan (2016).

Rotifers such as Brachionus falcatus, Anuraeopsis fissa and Trichocerca sp. showed their presence at station 2 and 3 and were completely absent from Station 1 . These rotifers commonly dwell in oligotrophic waters (Arora 1966). Their

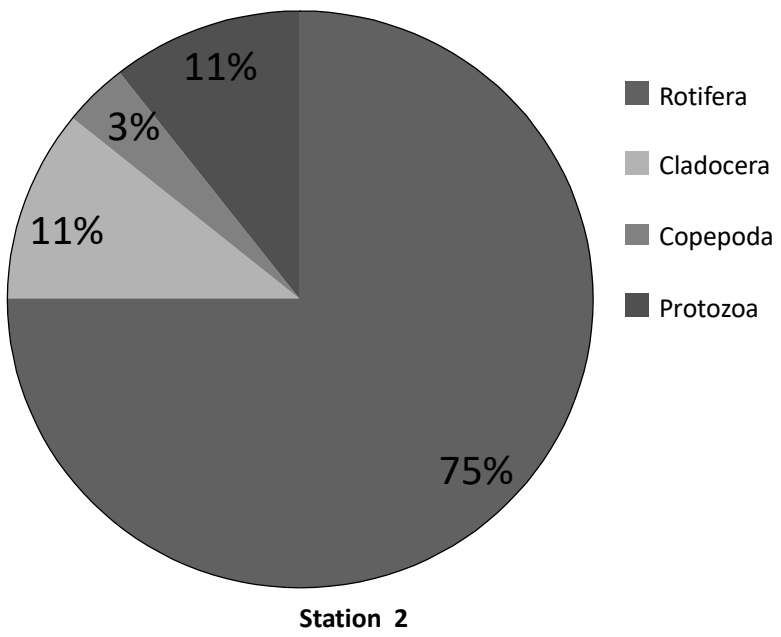

Fig. 3. Percentage composition of zooplankton at station 2

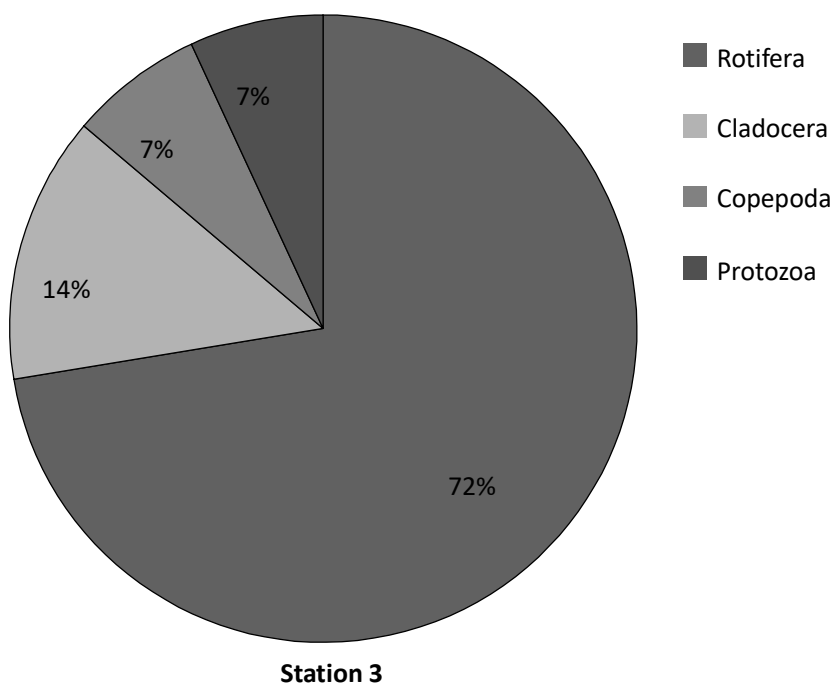

Fig. 4. Percentage composition of zooplankton at station 3 


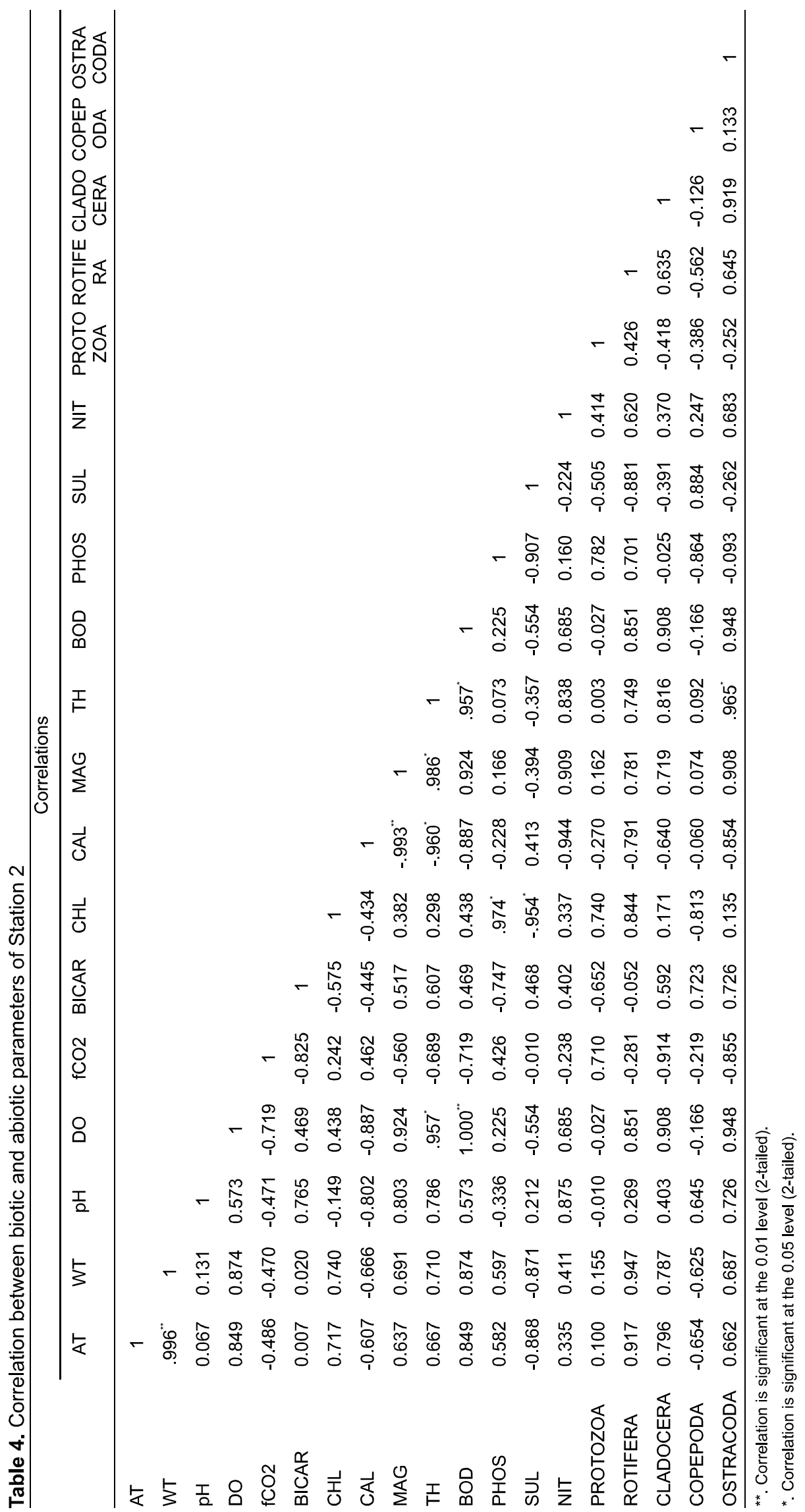




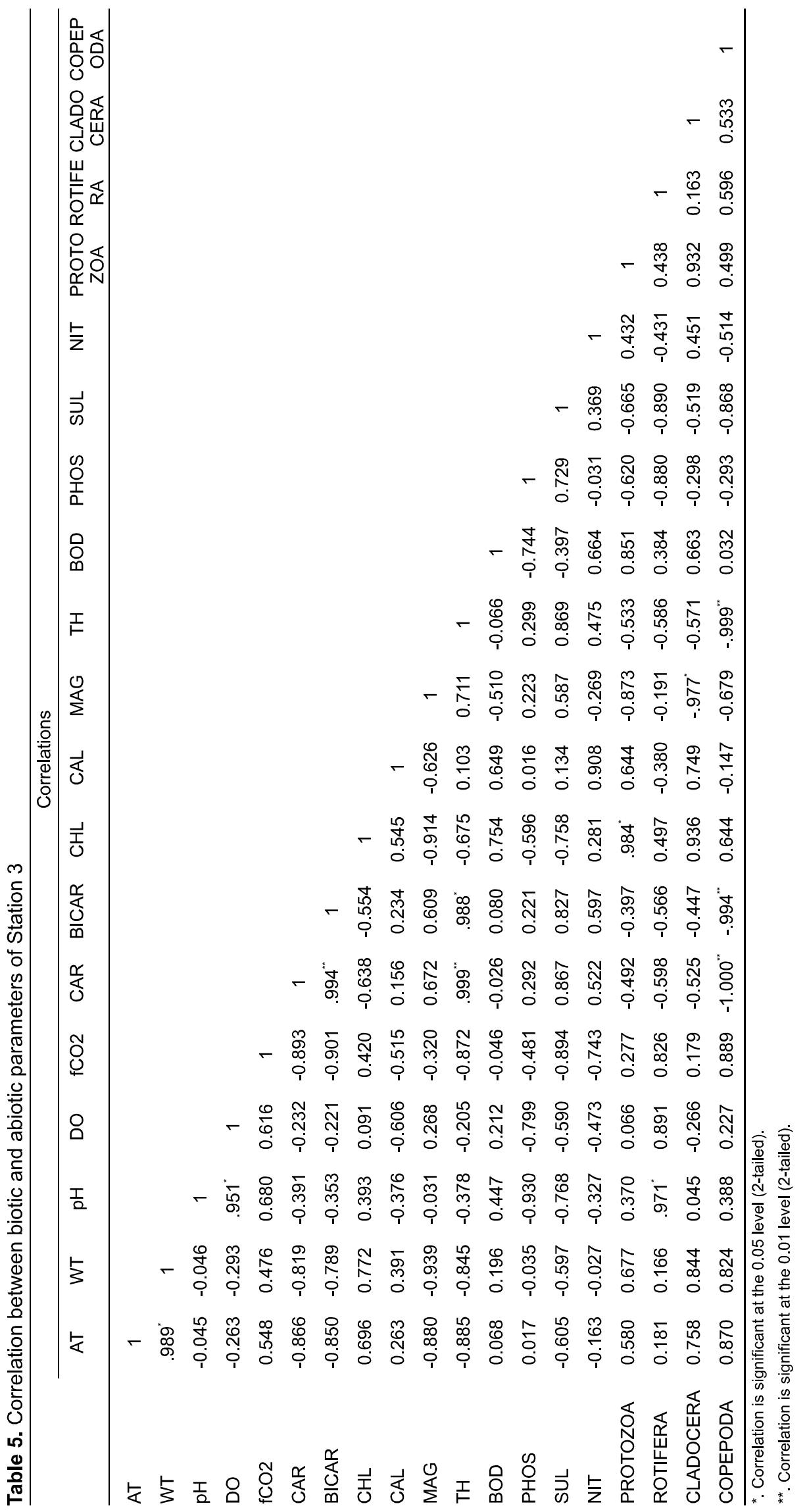


presence at Station 2 and Station 3 indicate comparatively less organic matter in these water bodies. Apart from rotifers, cladocerans also act as bioindicator of health of the aquatic system. Cladocerans like Moina brachiata, Chydorus sphaericus, Ceriodaphnia sp., Alona sp., Diaphanosoma sp. were commonly observed at Station 1 . These cladoceran species are considered as good indicators of eutrophic conditions by many workers (Ferdous and Muktadir 2009, Singh et al 2013) and their presence at Station 1 further authenticate the eutrophic nature of this water body. Protozoans such as Epistylis sp. and Vorticella sp. indicate presence of high amount of organic matter in any water body. Both these species were recorded from Station 1 in considerable number. Their abundance in a water body is an indicator of high trophic status (Singh et al 2013). Copepods, in general, flourish well in relatively stable environments and indicate good health of water body. In the present case, copepods were less abundant than other groups in all sites. Considering this data, Station 1 was found to have more organic load as compared to other two stations as this water body had many pollution tolerant and bioindicator species (Table 2). This station is tending fast towards eutrophism as evident by both biotic and abiotic parameter.

\section{CONCLUSION}

A well-marked correlation among biotic and abiotic components of water systems was observed. The three stations, situated at distant places of Jammu region, showed a total of 49 zooplankton species belonging to 5 groups. Various pollution indicator species like Brachionus calyciflorus, B. angularis, Keratella tropica, Polyarthra vulgaris, Filinia longiseta, Moina brachiata, and Chydorus sphaericus were reported. Ostracods being the only group showing selectivity for soft bottom and thus were present only at Station 1. Overall analysis of zooplankton revealed station 1 to be most inclined towards eutrophication as compared to the other two stations due to abundance of indicator species and this was also supported by abiotic data.

\section{ACKNOWLEDGEMENT}

The author is highly thankful to CSIR, New Delhi for providing financial assistance for the research.

\section{REFERENCES}

Adoni AD 1985. Workbook on limnology. Pratibha Publishers, C-10, Gour Nagar Sagar, India, p. 216.

Altaff K 2004. A manual of Zooplankton. University Grant Commision, New Delhi, p. 155.

APHA 1985. Standard methods of the examination of waste and waste water. $12^{\text {th }}$ American Public Health Association, New York.

Arora HC 1966. Rotifer as indicators of trophic nature of environments. Hydrobiologia 27(1-2): 146-159.

Edmondson WT 1992. Fresh Water Biology. $2^{\text {nd }}$ edition. International Books and Periodicals Supply Service.

Ferdous $Z$ and Muktadir AKM 2009. A review: Potentiality of zooplankton as bioindicator. American Journal of Applied Sciences 6(10): 1815-1819.

Kour S, Sharma N, Verma R, Kour S and Kumar V 2021. Analysis of correlation among zooplankton in two nearby ponds of Jammu region. Ecology, Environment and Conservation 27(1): 201208.

Kudo RR 1966. Protozoology. $5^{\text {th }}$ edition. Charles C Thomas, Springfield, Illinious, p. 1174

Michael RG and Sharma BK 1988. Fauna of India, Indian Cladocera, Director, Zoological Survey of India, Calcutta, p. 262.

Murkute VB and Chavan AW 2016. Report on rotifer diversity with reference to their role in eutrophication from lentic ecosystem at Bramhapuri, Dist: Chandrapur (MS) India. International Journal of Researches in Biosciences, Agriculture and Technology 16: 8-12.

Parmar TK, Rawtani D and Agarwal YK 2016. Bioindicators: the natural indicator of environmental pollution. Frontiers in Life Sciences 9(2): 110-118.

Pennak RW 1978. Freshwater invertebrates of United States. $2^{\text {nd }}$ edition. AWiley Interscience Publication.

Ramchandra TV, Rishiram R and Karthik B 2006. Zooplanktons as bioindicators: hydro biological investigation in selected Bangalore lakes. Technical Report, p. 115.

Singh UB, Ahluwalia AS, Sharma C, Jindal R and Thakur RK 2013. Planktonic indicators: A promising tool for monitoring water quality (early warning signals). Ecology, Environment and Conservation 19(13): 793-800.

Thakur RK, Jindal R, Singh UB and Ahluwalia AS 2013. Plankton diversity and water quality assessment of three freshwater lakes of Mandi (Himachal Pradesh, India) with special reference to planktonic indicators. Environmental Monitoring and Assessment 185(10): 8355-8373. 